\title{
Wetlands of Banjarbaru City in Last Four Decades
}

\author{
Syam'ani $^{1,2,3}$, Abdi Fithria ${ }^{1,2,3}, \&$ Eva Prihatiningtyas ${ }^{2,3}$ \\ ${ }^{1}$ Spatial Data Infrastructure Development Center (PPIDS), Lambung Mangkurat University \\ ${ }^{2}$ Faculty of Forestry, Lambung Mangkurat University \\ ${ }^{3}$ Center of Excellence Research Consortium for Sustainable Tropical Forest Management, Lambung \\ Mangkurat University
}

\begin{abstract}
The change of Banjarbaru City status into the central government of South Kalimantan Province, has the potential to increase the need for land. This directly affects wetlands conversion activities into other forms of land closure. This research aims to map the spatial distribution of wetlands, and the spatial distribution of wetlands conversion existing in Banjarbaru City in every decade over the last four decades, from the 1970s to the present. Wetlands spatial data are extracted from multitemporal satellite imagery, Landsat 5 in 1973, Landsat 5 in 1989, Landsat 5 in 1997, Landsat 5 in 2007, and Landsat 8 in 2016. The method used to extract wetlands is Object Based Image Analysis (OBIA), with Full Lambda-Schedule algorithm. The research results show that over the past last decades, the total area of Banjarbaru City's wetlands has been reduced continuously. The average total reduction rate is 534.5 hectares per decade or about 53.5 hectares per year, with a linear pattern over the past four decades.
\end{abstract}

Key words: Wetlands, Banjarbaru, OBIA, Feature Extraction, Landsat

\section{INTRODUCTION}

Banjarbaru City is one of the cities in South Kalimantan Province, Indonesia. The city began to be built in the 1950 s with status as administrative city. When the division of Kalimantan Province into 3 provinces, and then into 4 provinces, Banjarbaru is planned to become the capital of South Kalimantan Province.

Since 1999, Banjarbaru City is officially status as a municipality, which means already have their own government, which has an area of 371.3 square kilometers. And since 2011, the South Kalimantan Provincial Government moved the provincial government gradually from Banjarmasin City to Banjarbaru City.

The plan to move the capital of South Kalimantan Province to Banjarbaru City has the potential to cause the development of Banjarbaru City to grow faster. This will affect the increasing need for land, both for settlement, government offices, public facilities, business centers, and industry. Although initially, the location of Banjarbaru City was chosen in such

Correspondence: Syam'ani, Spatial Data Infrastructure Development Center (PPIDS), University of Lambung Mangkurat, Jl. Ahmad Yani, km. 35 Banjarbaru, Email: syamani.fhut@ulm.ac.id a way in drylands in the hilly area. However, some areas of Banjarbaru City are remained as wetlands.

Wetlands are ecosystems saturated with water, either seasonally or permanently. Wetlands are the link between the land and the water. They are transition zones where the flow of water, the cycling of nutrients, and the energy of the sun meet to produce a unique ecosystem characterized by hydrology, soils, and vegetation (EPA, 2004).

The rapid development of Banjarbaru City directly affects wetlands conversion activities into other landuses, primarily being dryland features. In some places, there is widespread massive wetlands conversion to residential areas like Kota Citra Graha, and several other areas.

For long-term area management, the conversion of wetlands in an area should be monitored and controlled in such a way. So that the future will not cause any serious environmental impact. The easiest and most efficient method to monitor wetlands conversion is by using remote sensing technology. With remote sensing technology, we can observe the face or spatial distribution of wetlands over time using multitemporal satellite imagery. Furthermore, we can calculate the rate of wetlands conversion over time. 
Wetlands are fairly easily visually interpreted over multispectral satellite images, such as the Landsat series. In Landsat 5 composite 543 or Landsat 8 composite image of 654 for example, tropical wetlands will generally be turquoise. This is because the wetlands of the tropics are generally dominated by green vegetation. Except for deep enough wetlands, such as lakes or rivers, will usually be blue.

The process of extracting wetlands above satellite imagery can be done manually, i.e., by delineation or digitization. Of course this technique is inefficient and of low consistency. The most efficient and accurate method is by automatic extraction or classification. Several methods of automatic classification can be used to extract wetlands, eg using multispectral classification, Normalized Difference Water Index (NDWI) transformation (McFeeters, 1996; Xu, 2006), Topographic Wetness Index (TWI) (Beven and Kirkby, 1979), segmentation image (Gonzalez and Woods, 2001) or Object Based Image Analysis (OBIA) (Blaschke, 2010), and so on. Of course these methods have their respective advantages and disadvantages.

This research aims to map the spatial distribution of wetlands, and the spatial distribution of wetlands conversion in Banjarbaru City in every decade during the last four decades, i.e., from the 1970s to the present. This information ought to lead the authorities in making the spatial planning policy Banjarbaru City, to pay more attention to the wetlands sustainability aspects that still remain in the city of Banjarbaru.

\section{MATERIAL AND METHOT}

This study takes the location of the entire administrative area of Banjarbaru City. Satellite imageries used are Landsat 1 MSS (Multispectral Scanner), Landsat 5 TM (Thematic Mapper), and Landsat 8 OLI (Observation Land Imager). The entire area of Banjarbaru City is covered by Landsat 1 path/row 126/062, and Landsat 5 and 8 path/row $117 / 062$. Image acquisition time was chosen to represent the 1970s (decade 0/baseline), 1980s (decade 1), 1990s (decade 2), 2000s (decade 3), and 2010s (decade 4).

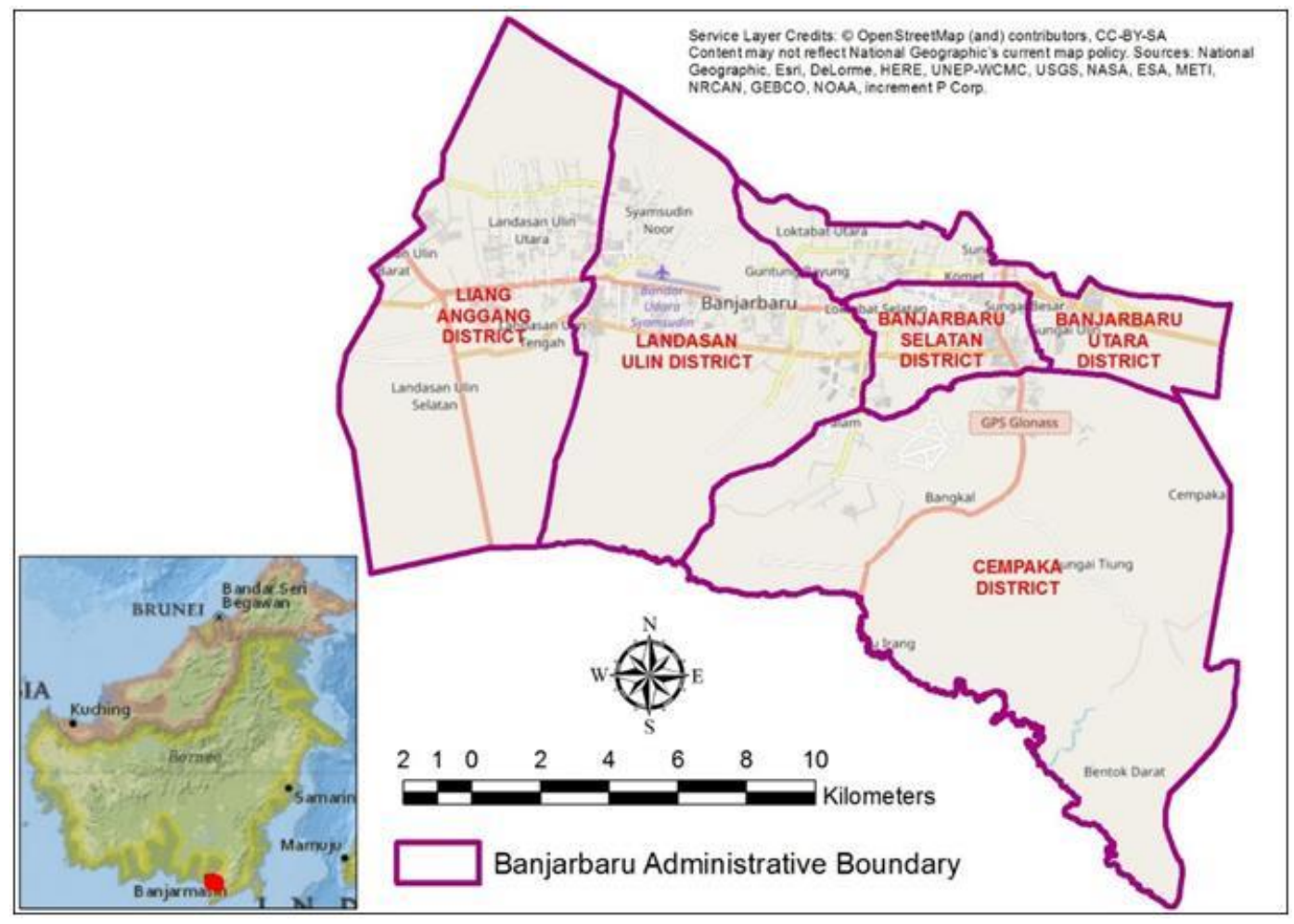

Figure 1. Research location

In case, the consideration of choosing satellite imageries, the absence of clouds and Journal of Wetlands Environmental Management Vol 6, No 2 (2018) 131 - 138 http://dx.doi.org/10.20527/jwem.v6i2.183 fog is one of the main considerations. This affects the inequality of the satellite imageries 
Available on line at:

http://ijwem.unlam.ac.id/index.php/ijwem

acquisition time interval $(\ldots \ldots, \ldots)$. Because choosing a truly clean image of clouds and fogs at the same year interval is a very difficult or almost impossible for a tropical country like Indonesia. Also, we can not find the ideal Landsat imageries like this for Banjarbaru City in Landsat 1 and 5. So in the decade of 2010an we use Landsat 8 year 2016 .

The satellite imagery used in this study can be seen in detail in Figure 3. We chose to use Landsat 5 instead of Landsat 7 in the decade of 2000s, with the consideration that after 2003 p ISSN: 2354-5844

e ISSN: $2477-5223$

ETM + sensors on Landsat 7 ETM+ sensor suffered mechanical damage, resulting in stripped digital imageries. While Landast 8 itself new orbits in 2013.

Because of the inequalities of satellite acquisition time intervals every decade (which are ideally every 10 years), in this study we do rescaling time intervals. That is by dividing the wetlands area changes by the actual time interval, then multiplying by 10 years which was enable as to estimate the change of wetlands area every decade or 10 years.

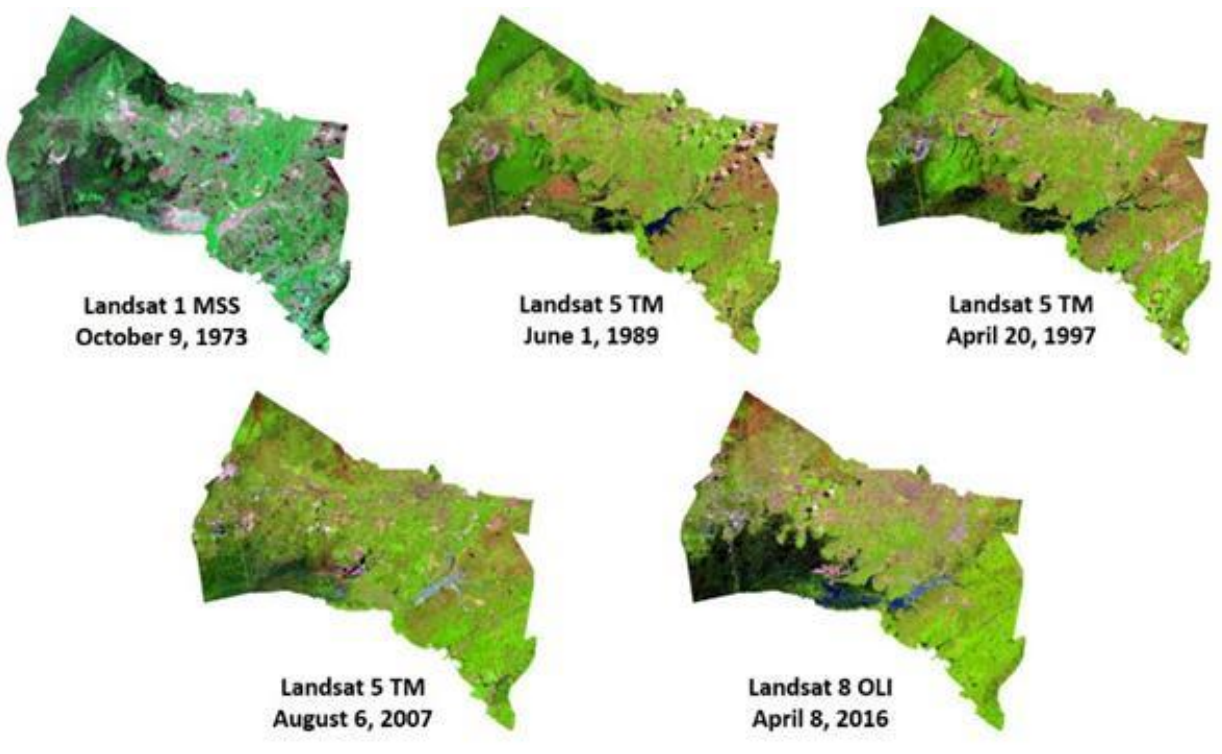

Figure 2. Landsat Imageries in every decades

The method of wetlands and drylands classification used in this research is image segmentation or OBIA, with Full LambdaSchedule algorithm (as described by Robinson et al., 2002). In addition to its practicality and accuracy, this method is chosen because of the character of wetlands that are composite. Wetlands in the tropics region like Indonesia generally consist of water objects, vegetation, as well as soil. To ensure the results of the wetlands classification, in this study we also conducted a direct verification to the field. Although in this study we did not test the accuracy of the classified spatial data.

\section{RESULTS AND DISCUSSIONS}

The results of wetlands extraction from time to time indicate that the wetlands of Banjarbaru City are located in the West and Southwest of this city. Most of the wetlands in this region are swamps, in addition to swamp forests, peatlands, and community agricultural areas (rice fields). Furthermore, most of the wetlands in Banjarbaru City are temporal or seasonal wetlands. That is, the new land will be wet in the rainy season. While the peatlands in Banjarbaru City are located in the western part of the city. 

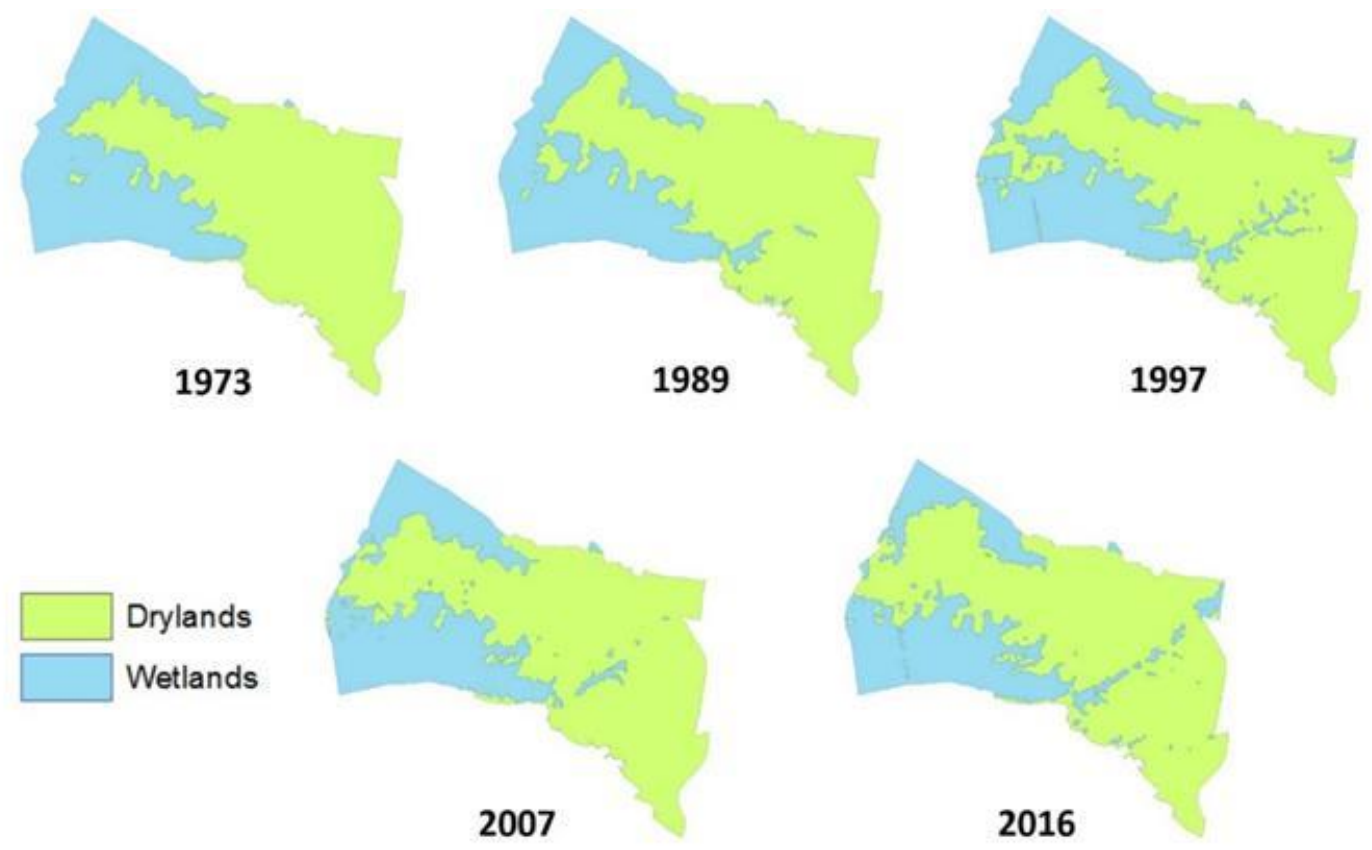

Figure 3. The distribution of Banjarbaru wetlands in every decade

Table 1. Banjarbaru wetlands area

\begin{tabular}{cc}
\hline Year & Area (Hectares) \\
\hline 1973 & $11,920.10$ \\
\hline 1989 & $11,327.70$ \\
\hline 1997 & $11,041.40$ \\
\hline 2007 & $10,486.20$ \\
\hline 2016 & $9,716.88$ \\
\hline
\end{tabular}

Within the last four decades, the Banjarbaru City wetlands are continuously reduced (Figure 4 and Table 1). This is the impact of development and the growing population. In general, wetlands in Banjarbaru are converted for settlement purposes, government offices, business centers, road construction, industry, and so on.

In addition to diminishing, the results of this study also indicate that there is a new wetlands emergence in Banjarbaru. Most of the newly emerging wetlands in Banjarbaru are artificial wetlands that made by man by diamond mining activities in Cempaka District, making of new rice fields in Sungai Ulin Sub-district, and the creation of irrigation canals that pass through Mentaos Sub-district. However, the rate of occurrence of new wetlands is not as fast as wetlands lost in each decade. 


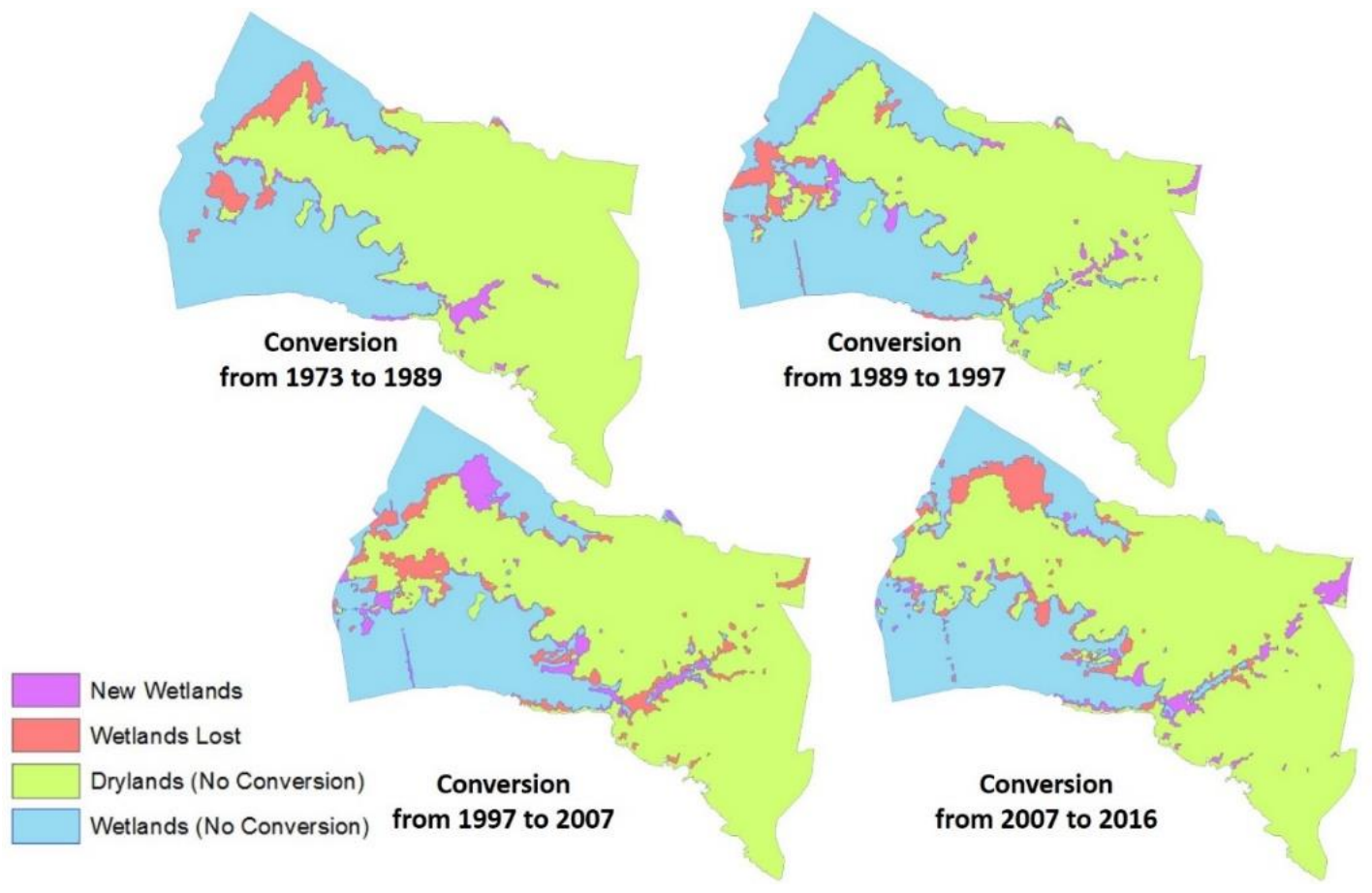

Figure 4. Banjarbaru wetlands conversion

Table 2. Banjarbaru wetlands area in different years

\begin{tabular}{ccccc}
\hline $\begin{array}{c}\text { Types of } \\
\text { Conversion }\end{array}$ & $\begin{array}{c}\text { Converted area } \\
\text { from 1973 to } \\
\text { 1989 (Hectares) }\end{array}$ & $\begin{array}{c}\text { Converted area } \\
\text { from 1989 to 1997 } \\
\text { (Hectares) }\end{array}$ & $\begin{array}{c}\text { Converted area } \\
\text { from 1997 to 2007 } \\
\text { (Hectares) }\end{array}$ & $\begin{array}{c}\text { Converted area } \\
\text { from 2007 to 2016 } \\
\text { (Hectares) }\end{array}$ \\
\hline $\begin{array}{c}\text { Formed } \\
\text { Wetlands }\end{array}$ & 609.56 & 773.059 & $1,258.59$ & $1,003.16$ \\
\hline Wetlands Lost & $1,201.90$ & $1,059.35$ & $1,813.84$ & $1,772.46$ \\
\hline
\end{tabular}

Table 3. Average area of new wetlands and wetlands lost in every decade

\begin{tabular}{ccccc}
\hline $\begin{array}{c}\text { Types of } \\
\text { Conversion }\end{array}$ & $\begin{array}{c}\text { Decade 1 } \\
\text { (Hectares) }\end{array}$ & $\begin{array}{c}\text { Decade 2 } \\
\text { (Hectares) }\end{array}$ & $\begin{array}{c}\text { Decade 3 } \\
\text { (Hectares) }\end{array}$ & $\begin{array}{c}\text { Decade 4 } \\
\text { (Hectares) }\end{array}$ \\
\hline $\begin{array}{c}\text { Formed } \\
\text { Wetlands }\end{array}$ & 380.97 & 966.32 & $1,258.59$ & $1,114.62$ \\
\hline Wetlands Lost & 751.19 & $1,324.19$ & $1,813.84$ & $1,969.40$ \\
\hline
\end{tabular}

As already mentioned in Method section, that in the wetlands conversion analysis in this study, we performed a rescaling time interval. This is because the time interval of multitemporal image acquisition is not the same. Thus the area of wetlands conversion for each decade is the product of the estimated annual rate of land conversion in the decade over a decade or ten years. From 1973 to 1989 for example, which has a time interval of 16 years, and Banjarbaru City wetlands lost during this period was 1,201.9 hectares. To calculate the area of wetlands lost in this period, 1.201.9 divided by 16 and then multiplied by 10 , resulting 751.19 hectares. 


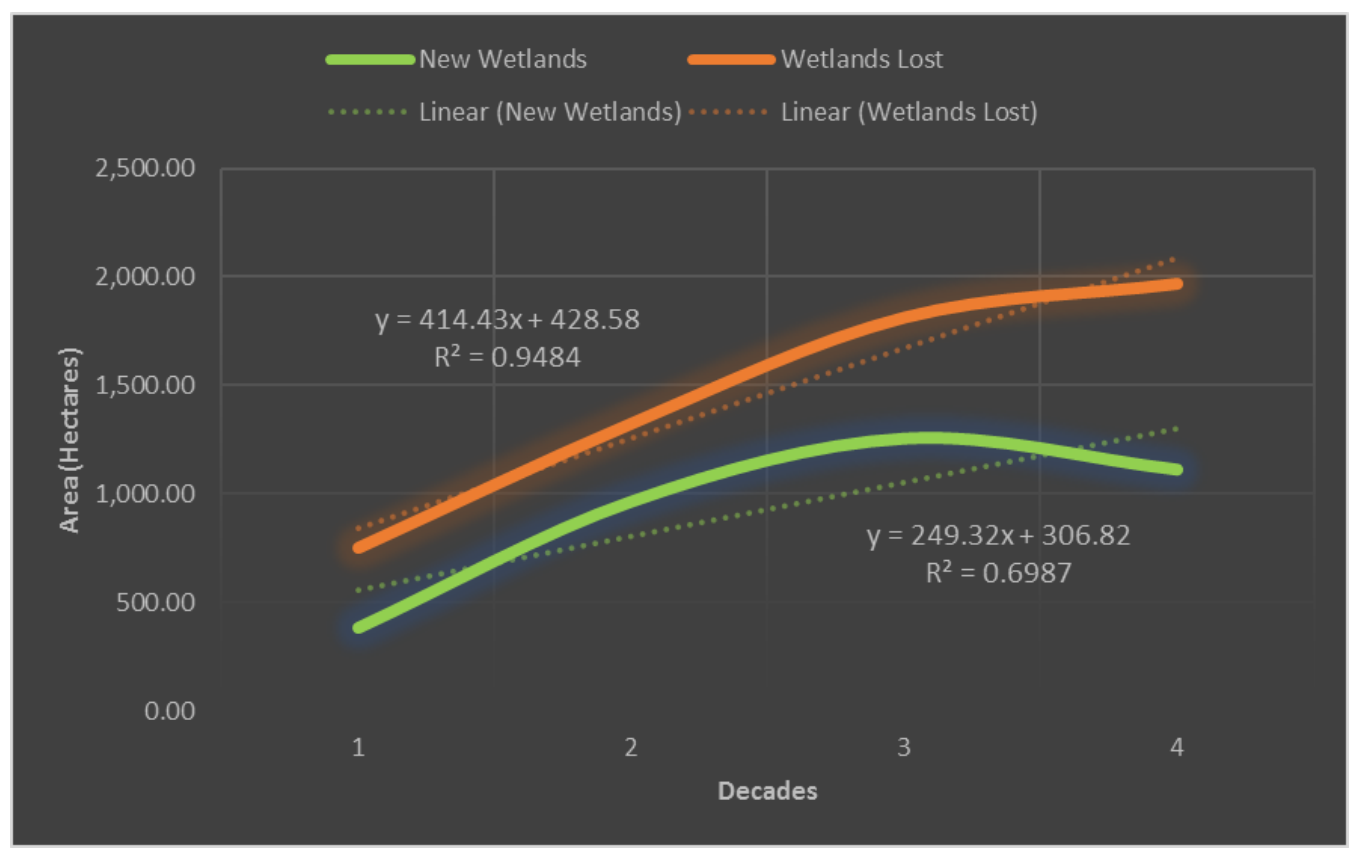

Figure 6. Average area of new wetlands and wetlands lost in every decade

The result of plotting up the average chart of new wetlands and the wetlands lost of Banjarbaru City for every decade, shows that the pattern of wetlands lost for each decade tends to be linear increased. While the pattern of occurrence of new wetlands for each decade is somewhat hyperbolic, and tends to decline presently. This may be an indication of a stagnation in the opening of new mining pits in diamond mining in Banjarbaru City. One of them is to stop operation of diamond mining PT. Galuh Cempaka in 2009. Results from diamond mining activities of PT. Galuh Cempaka presently produces two lakes, which is now used as a tourist attraction, namely Lake Seran and Lake Cermin.

Table 4. Net wetlands lost

\begin{tabular}{ccccc}
\hline $\begin{array}{c}\text { From } \\
\text { Year }\end{array}$ & To Year & $\begin{array}{c}\text { Time Interval } \\
\text { (Years) }\end{array}$ & $\begin{array}{c}\text { Total Net wetlands Lost } \\
\text { (Hectares) }\end{array}$ & $\begin{array}{c}\text { Average Total Net } \\
\text { Wetlands Lost Each } \\
\text { Decade (Hectares) }\end{array}$ \\
\hline 1973 & 1989 & 16 & 592.40 & 370.25 \\
\hline 1989 & 1997 & 8 & 286.30 & 357.875 \\
\hline 1997 & 2007 & 10 & 555.20 & 555.2 \\
\hline 2007 & 2016 & 9 & 769.32 & 854.8 \\
\hline \multicolumn{5}{r}{ Average } \\
\hline
\end{tabular}

Tables 2 and 3 and Figure 6 show that the average occurrence of new wetlands of Banjarbaru City is always lower than wetlands lost for every decade. So the total net wetlands lost for every decade is always positive, as shown in Table 4. This means, the total wetlands of Banjarbaru City is reduced continuously. The total net wetlands lost itself is obtained by subtracting wetlands lost with formed wetlands for each decade. If averaged, the rate of reduced wetlands Banjarbaru City is 534.53 hectares for every decade, or about $\mathbf{5 3 . 5}$ hectares for each year. 


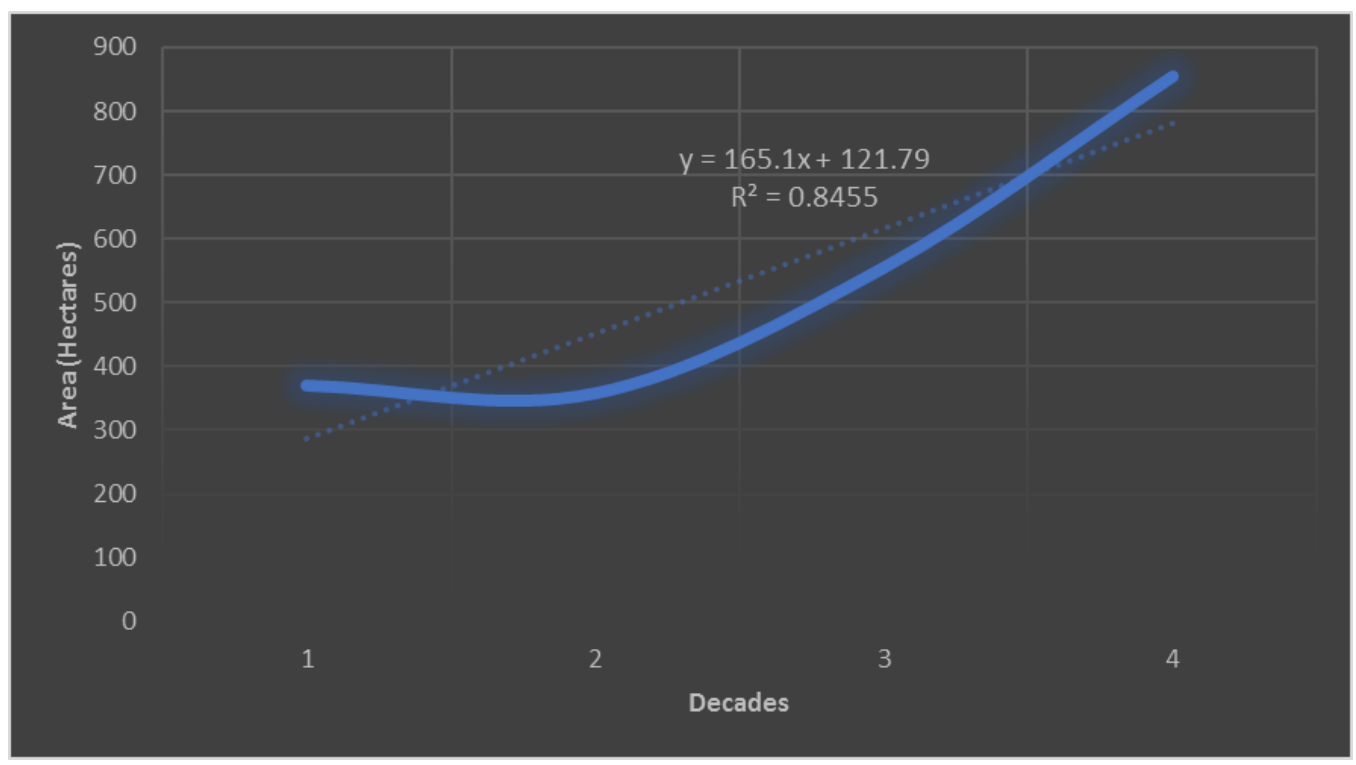

Figure 7. Average total net area of wetlands lost in every decade

The chart in Figure 7 shows that the net average total wetlands area lost in Banjarbaru City per decade tends to be linear. So that the decrease of wetlands of Banjarbaru city of 534.53 hectares per decade or 53.5 hectare per year can be assumed relatively constant by time. If this is true, then in the current year (2017), the wetlands area of Banjarbaru City will have $9,663.38$ hectares remaining. And if conditions like the previous four decades continue without any conservation effort, the wetlands of Banjarbaru City will run out in 18 decades or 180 years into the future.

\section{CONCLUSSIONS}

Over the past four decades, the total area of the Banjarbaru City wetlands has been reduced continuously. Despite the fact that every decade there is also a new wetlands. However, the rate of wetlands formation is not as fast as the wetlands lost each decade. Furthermore, the decrease in wetlands of Banjarbaru City have reduced at the rate of 534.5 hectares per decade or about 53.5 hectares per year. While the rate of wetlands formation shows stagnation in since the last two decades.

\section{REFERENCES}

Beven, K.J. and Kirkby, M.J., 1979, A Physically Based, Variable Contributing Area Model of Basin Hydrology,
Hydrolological Sciences Bulletin, 24, pp. 4369.

Blaschke, T., 2010, Object Based Image Analysis for Remote Sensing, ISPRS Journal of Photogrammetry and Remote Sensing, 65 (2010), pp. 2 - 16.

Gonzalez, R.C. and Woods, R.E., 2001, Digital Image Processing (Second Edition), Prentice-Hall, Inc., Upper Saddle River, New Jersey.

Jensen, J.R., 1996, Introductory Digital Image Processing: A Remote Sensing Perspective (Second Edition), Prentice-Hall, Inc., Upper Saddle River, New Jersey.

McFeeters, S.K., 1996, The Use of the Normalized Difference Water Index (NDWI) in the Delineation of Open Water Features, International Journal of Remote Sensing, 17 (7), pp. 1425-1432.

Richards, J.A. and Jia, X., 2006, Remote Sensing Digital Image Analysis: An Introduction (Fourth Edition), SpringerVerlag, Berlin.

Robinson, D. J., Redding, N. J., and Crisp, D. J., 2002, Implementation of a Fast Algorithm for Segmenting SAR Imagery, Scientific and Technical Report, 01 January 2002, Australia: Defense Science and Technology Organization.

United States Environmental Protection Agency (EPA), 2004, Wetlands Overview, EPA 843F-04-011a, Office of Water, December 2004. 
Open Water Features in Remotely Sensed 